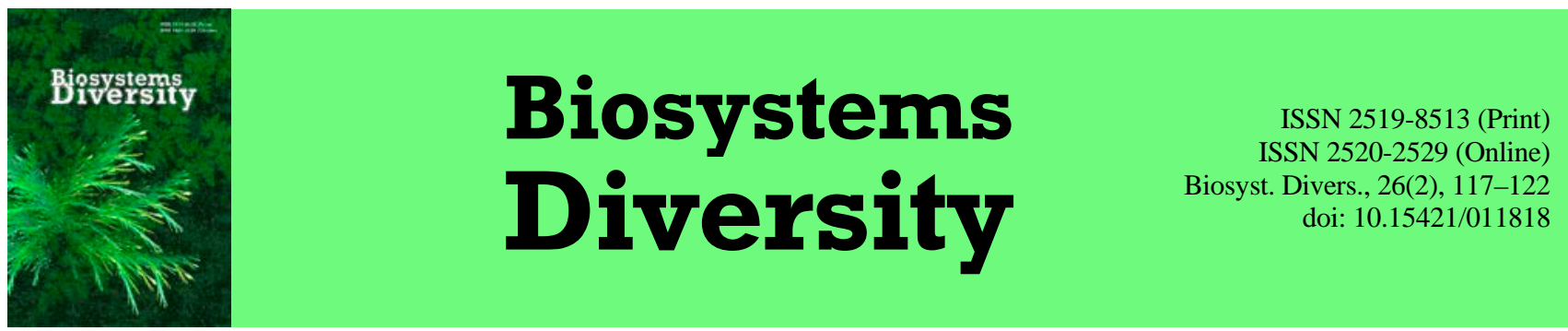

\title{
Strusture, biomass and production of the biotic component of the ecosystem of an growing eutrophic reservoir
}

\author{
A. I. Kopylov, D. B. Kosolapov, V. I. Lazareva, N. M. Mineeva, E. G. Pryanichnikova \\ Papanin Institute for Biology of Inland Waters of the Russian Academy of Sciences, Borok, Russia
}

Article info
Received 11.04.2018
Received in revised form
13.05.2018
Accepted 15.05.2018

Papanin Institute for Biology of Inland Waters of the Russian Academy of Sciences, Borok,

Yaroslavl oblast, 152742, Russia.

Tel.: +7-485-472-40-42

E-mail:

kopylov@ibiw.yaroslavl.ru,

dkos@ibiw.yaroslavl.ru

\begin{abstract}
Kopylov, A. I., Kosolapov, D. B., Lazareva, V. I., Mineeva, N. M., \& Pryanichnikova, E. G. (2018). Structure, biomass and production of the biotic component of the ecosystem of an growing eutrophic reservoir. Biosystems Diversity, 26(2), 117-122. doi:10.15421/011818
\end{abstract}

Using our own data and data from the literature, we assessed the total biomass of the biotic component of the ecosystem of the Ivankovo Reservoir (Upper Volga, Russia), a eutrophic reservoir which is becoming overgrown with macrophytes. The biotic component of freshwater ecosystems is formed by communities of multicellular and unicellular organisms and viruses in the water layer (plankton) and bottom sediments (benthos) and also macrophytes and autotrophic and heterotrophic organisms growing on their surface (epiphyton). The biomass of the biotic component of the Ivankovo Reservoir equaled 39,853 tons C. Plankton, benthos and macrophytes with epiphyton equaled 3.6\%, $41.6 \%$ and $54.8 \%$ of the total biomass respectively. We determined the contribution of higher aquatic plants, algae, cyanobacteria, heterotrophic bacteria, viruses, protozoans, multicellular invertebrates and fish to the formation of total biomass. The largest share was taken up by higher aquatic plants (54.5\%). The second largest share was taken by heterotrophic bacteria (37.4\%), most of which live in the bottom sediments. The high concentration of bacteria and invertebrates in the bottom sediments indicate significant provision of the organic substrates from the water column. The biomass of fish, the highest trophic link in the reservoir, equaled $15.0 \%$ of the biomass of their potential food substrates, invertebrate animals, and $0.7 \%$ of the total biomass of the biotic component. The greater part of the autochthonous organic compound in the reservoir is formed as a result of activity of phytoplankton, which provides $69.4 \%$ of total primary production of macrophytes, phytoepiphyton, phytoplankton and phytobenthos. The total primary production during the vegetation period was approximately forty times higher than the annual production of the fish. Currently, the share in the phytoplankton of large colonial cyanobacteria not consumed by zooplankton, the share of non-heterocystic species of cyanobacteria capable of heterotrophic feeding and the share of mixotrophic flagellates is increasing. Eutrophication of the reservoir is significantly stimulated by the development of macrophytes, and, presumably, the contribution of macrophytes to the total primary production of the reservoir will continue to increase.

Keywords: groups of hydrobionts; communities of hydrobionts; structure; products; reservoir

\section{Introduction}

The biotic component of freshwater ecosystems is formed by the communities of multicellular and unicellular organisms and viruses which live in the water column (plankton) and bottom sediments (benthos), and also macrophytes and autotrophic and heterotrophic organisms growing on their surface (epiphyton). Currently, in freshwater reservoirs, carbon of organic compounds synthesized by the primary producers (higher aquatic plants, algae, cyanobacteria, photosynthesizing and chemosynthetic bacteria), is delivered to higher trophic levels, and, finally, to the highest link - to fish via different routes: phytoplankton (phytobenthos, macrophytes) - invertebrates - fish (direct food chain); "dead" organic compound of autotrophic organisms (detritus of vegetative origin) - bacteria - invertebrates - fish (detritus of the food chain); dissolved organic matter released by autotrophic organisms during photosynthesis (autotrophic DOM) - bacteria - protozoa (microbial "loop") - multicellular invertebrates - fish (Sommaruga, 1995; Wetzel, 1995; Porter, 1996; Pomeroy et al., 2007). Also, heterotrophic bacteria involve a significant amount of allochthonous organic carbon into the trophic webs of aquatic ecosystems, especially such as rivers and reservoirs, and also areas affected by anthropogenic pollution.

Quantitative studies of flows of carbon and energy in trophic webs, and finally, determination of the pattern of structural-functional organisation of freshwater ecosystems, and also the assessment of their transformations which occur as a result of anthropogenic impact and climate change require factual data on the structure, biomass and products of biological communities of the water layer, bottom sediments and the entire biotic component (Stone et al., 1993; Kazantseva, 2003; MacKay et al., 2009; Sipkay et al., 2009). The literature includes a much larger amount of data on the significance of the total biomass of plankton and the contribution of algae and cyanobacteria, heterotrophic bacteria, protozoa and, multicellular zooplankton to its formation in lakes and reservoirs of different trophic status than on benthos and epiphyton communities (Christoffersen et al., 1990; Del Giorgio \& Gasol, 1995; Fahnenstie et al., 1998; Straile, 1998; Hart \& Stone, 2000; Degermendzhy, Gulati, 2002; Comerma et al., 2003; Kazantseva, 2003; Auer et al., 2004; Chróst et al., 2009; Kopylov et al., 2010, 2014). Significant structural components of many small freshwater bodies are higher aquatic autotrophic and heterotrophic organisms and plant growing on their surface (epiphyton) (Vadeboncoeur \& Steinman, 2002; Cronin et al., 2006).

At the same time, no studies have been conducted which focus on the structure of the entire biotic component of a large freshwater body, including the main groups of hydrobionts: macrophytes, algae and cyanobacteria, viruses, heterotrophic bacteria, protozoa, multicellular invertebrates and fish.

The Ivankovo Reservoir was created in 1937 and is one of the oldest in the cascade of the Volga Reservoirs. The peculiarity of the reservoir is its shallowness: a water area less than $2 \mathrm{~m}$ in depth covers around $48 \%$ of the reservoir's area at normal head water level. Since 
the 1970s, according to the content of chlorophyll "a" in the water, this reservoir has been characterized as eutrophic, and the extent of its overgrowth by higher aquatic plants reached $17 \%$ of the water surface area in 1957 (Ekzertsev, 1958; Pyrina \& Lyashenko, 2005). During the existence of the reservoir, multiple data have been collected on the structural-functional characteristics of the communities of autotrophic and heterotrophic organisms which live in the water layer and bottom sediments (Ekzertsev, 1978; Abakumov et al., 2000; Kopylov, 2001). However, the structure of the entire biotic component of the ecosystem of this water body has not since been analyzed.

This study constitutes the first attempt to assess the total biomass of the biotic component of the ecosystem of a eutrophic reservoir overgrown by macrophytes, Ivankovo Reservoir (Upper Volga), and to determine the contribution of macrophytes with epiphyton, plankton, benthos and the communities of various autotrophic and heterotrophic organisms to its formation, and also to determine the primary production of the organic matter in the water body and determine the role of macrophytes, phytoplankton, phytoepiphyton and phytobenthos in this process.

\section{Materials and methods}

In the study, we used the results of our research conducted in the Ivankovo Reservoir in July-August of 2005-2012, particularly: assessing the primary production of phytoplankton, concentration of chlorophyll "a" in the water, biomass of virio- and bacterioplankton, virio- and bacteriobenthos (in the upper $2 \mathrm{~cm}$ layer of the bottom sediments), bacterioepiphyton, plankton and benthos heterotrophic nanoflagellates, plankton ciliates, multicellular zooplankton and macrozoobenthos (Kopylov \& Kosolapov, 2008; Kopylov et al., 2011, 2015; Rybakova \& Kopylov, 2017). Also we used the literature data on biomass and production of phytobenthos, content of chlorophyll in the epiphyton and benthos, higher aquatic plants and meiobenthos (Ekzertsev, 1978; Devyatkin, 1983; Kopylov, 2001; Shcherbina, 2002). The surveys of plankton and benthos macroorganisms were conducted in the same areas of the Reservoir. Because there are no data on tempi of epiphyton photosynthesis, the number of viruses and heterotrophic nanoflagellates in epiphyton, concentration of benthos ciliates and Sarcodina in the Ivankovskoe Reservoir, we used the data on another reservoir in the Upper Volga - the Rybinskoe Reservoir (Myl'nikova, 1977; Kopylov et al., 2014).

The ichthyomass was assessed using the data on the Reservoir's mean biomass of pelagic and demersal fish in August 1982 and 1985: $4.6 \pm 3.8$ (range $0.4-16.1$ ) and $1.7 \pm 0.8(0.2-3.8) \mathrm{t} / \mathrm{km}^{2}$ respectively (Poddubnyy, 1988).

The biomass of phytoplankton, expressed in carbon units, was determined on the assumption that the concentration of chlorophyll "a" is: $\mathrm{C}=25 \times$ [chlorophyll] (Reynolds, 2006). We assumed that the content of carbon in the wet material of phytoplankton equals $10 \%$ (Rodhe, 1948; Strickland, 1960).

The carbon content in the cells of heterotrophic bacteria (C, fg $\mathrm{C} /$ cell) was calculated using the following allometric equation: $\mathrm{C}=120 \times \mathrm{V}^{0.72}$, where $\mathrm{V}$ - cell volume, $\mu \mathrm{m}^{3}$ (Norland, 1993). The carbon concentration in 1 virus particle was considered to equal $0.055 \mathrm{fg} \mathrm{C}$ (Steward et al., 2007). We assumed that the content of carbon in wet biomass of heterotrophic nanoflagellates equaled 22\% (Børsheim \& Bratbak, 1987), ciliates - 13\% (Turley et al., 1986), metazooplankton $5 \%$ (Dumont et al., 1975). Food energy of meiobenthos was assumed to equal $1 \mathrm{cal} / \mathrm{mg}$, macrozoobenthos $-0.8 \mathrm{cal} / \mathrm{mg}$ of raw mass. We assumed that the food energy of pelagic fish equaled $1.5 \mathrm{cal} / \mathrm{mg}$, demersal fish $-1.1 \mathrm{cal} / \mathrm{mg}$ of raw mass (Kolpakov, 2016). In the calculations, we accepted that the content of the organic matter in wet biomass of macrophytes equals 14\% (Papchenkov, 2013), and $1 \mathrm{~g}$ of organic matter of macrophytes is equivalent to $0.5 \mathrm{~g}$ of organic carbon (Zhukova, 2005).

For converting different units of calculation, we used the following ratios: $1 \mathrm{mg} \mathrm{C}=3.333 \mathrm{mg} \mathrm{O}$ and $\mathrm{mg} \mathrm{C}=10.1 \mathrm{cal}$.

During the comparison of the data, we used mean values of the parameters and the standard errors of the average.

\section{Results}

Hydrological-hydrochemical characteristic of the ecosystem. The Ivankovo Reservoir is the first level of the Volga-Kama cascade of reservoirs. Normal head water level in the reservoir is $124 \mathrm{~m}$, full capacity at normal head water level is $1120 \mathrm{M} \mathrm{m}^{3}$, the surface area of the water body is $327 \mathrm{~km}^{2}$, length - $134 \mathrm{~km}$, average depth $-3.4 \mathrm{~m}$. The Reservoir is distinctive for having a stable level of water throughout the summer-autumn period (Ekzertsev, 1978; Avakyan et al., 1987).

The Reservoir is rich in biogenic elements - the concentration of its main elements in the water $(80-90 \mu \mathrm{g} / \mathrm{l}$ of the total phosphorus and $1.3-1.5 \mathrm{mg} / \mathrm{l}$ of total nitrogen on average for separate reaches, Kopylov (2001)) corresponds to the norm for eutrophic water bodies. The average surface water temperature (near the bottom) for the Reservoir in the second half of summer equaled $23.5 \pm 0.4^{\circ} \mathrm{C}(21.9 \pm$ $\left.0.2^{\circ} \mathrm{C}\right)$ in 2005 , and $23.8 \pm 0.3^{\circ} \mathrm{C}\left(20.1 \pm 0.4^{\circ} \mathrm{C}\right)$ in 2012 . The mean transparency of the water as measured by Secchi disk in 2005 and 2012 was the same: $85 \pm 4$ and $85 \pm 3 \mathrm{~cm}$ in 2005 and 2012 respectively. The content of oxygen dissolved in water in the surface and prebottom horizons in 2005 ranged within 5.9-9.7 and 0.02-7.20 mg/l respectively, and 6.4-8.9 and 0.4-5.5 mg/l respectively in 2012 .

Plankton. The total biomass of the plankton community in the Reservoir equaled 1,448.8 $\mathrm{t}$ C. The main contribution to its formation was made by phytoplankton (Table 1). In relation to the contribution to the plankton biomass, the heterotrophic bacteria took second place. The proportion of the total biomass of the food objects (phytoplankton and bacterioplankton) to the biomass of their consumers (nonpredatory zooplankton) equaled $6: 1$, and the proportion of the biomass of non-predatory to the predatory zooplankton equaled $3: 1$, the proportion of the total biomass of the zooplankton to the fish was $1: 1$. It is important to note that a significant share of the phytoplankton was represented by large colonial cyanobacteria, and due to the large sizes of their colonies they were not consumed by the zooplankton.

In the Ivankovo Reservoir, the heterotrophic bacterioplankton is represented by free-swimming single cells (on average, $79.36 \pm$ $2.30 \%$ of the total biomass of bacterioplankton); bacteria attached to detritus particles of $5-100 \mu g$ (14.92 $\pm 1.53 \%$ of the bacterioplankton biomass) size; and bacterial filaments (3.00 $\pm 0.65 \%)$. Therefore, heterotrophic bacteria can serve as food objects both for a large number of protozoa species, and for thin and large multicellular filtrators. The number of detritus particles inhabited by the bacteria ((34.2 \pm $7.0) \times 10^{3}$ particles $/ \mathrm{ml}$ ), equaled $50.7 \%$ of the total number of detritus particles of size less than $100 \mu \mathrm{g}\left((67.5 \pm 15.5) \times 10^{3}\right.$ particles $\left./ \mathrm{ml}\right)$ (Kopylov \& Kosolapov, 2008). According to our assessments, at average diameter of a detritus particle equaling $11 \mu \mathrm{g}$, only the mass of small detritus particles inhabited by the bacteria $\left(2351 \mathrm{mg} \mathrm{C} / \mathrm{m}^{3}\right)$ is 1.6 times larger than the total plankton biomass.

\section{Table 1}

Mean reservoir values ( \pm mean error) of the number $(\mathrm{N})$ and biomass (B) of the main groups of plankton organisms and their shares (\%) in the total biomass of the Ivankovo Reservoir

\begin{tabular}{|c|c|c|c|c|c|}
\hline \multirow[b]{2}{*}{ Component } & \multirow[b]{2}{*}{$\mathrm{N}$, ind. $/ \mathrm{m}^{3}$} & \multicolumn{4}{|c|}{ B } \\
\hline & & $\mathrm{mg} / \mathrm{m}^{3}$ & $\mathrm{mg}$ & $\begin{array}{l}\text { t C/water } \\
\text { body }\end{array}$ & $\begin{array}{c}\% \text { of plankton } \\
\text { biomass }\end{array}$ \\
\hline Phytoplankton & $-^{*}$ & $24 \pm 6^{* *}$ & 600 & 672.0 & 46.4 \\
\hline Bacteria & $(11.9 \pm 1.9) \times 10^{12}$ & $1255 \pm 75$ & 285 & 319.2 & 22.1 \\
\hline Viruses & $(55.2 \pm 9.9) \times 10^{12}$ & - & 3 & 3.4 & 0.2 \\
\hline Flagellates & $(3.1 \pm 0.3) \times 10^{9}$ & $154 \pm 17$ & 34 & 38.1 & 2.6 \\
\hline Ciliates & $(12.7 \pm 0.5) \times 10^{5}$ & $215 \pm 14$ & 28 & 31.4 & 2.2 \\
\hline $\begin{array}{l}\text { Non-predatory } \\
\text { zooplankton }\end{array}$ & $(180 \pm 88) \times 10^{3}$ & $1921 \pm 815$ & 96 & 107.5 & 7.4 \\
\hline $\begin{array}{l}\text { Predatory } \\
\text { zooplankton }\end{array}$ & $(48 \pm 20) \times 10^{3}$ & $962 \pm 395$ & 48 & 53.8 & 3.7 \\
\hline Pelagic fish & - & 1343 & 199 & 223.4 & 15.4 \\
\hline
\end{tabular}

Note: ${ }^{*}$ - here and in the Tables $2-4$, dashes indicate absence of data; ** - chlorophyll content.

Macrophytes and epiphyton. Currently, the extent of overgrowth of the Ivankovo Reservoir water area with higher aquatic plants equals 
$29.2 \%$ of the water surface area, and their biomass weighs 310 thousand $\mathrm{t}$, which corresponds to 43.4 thousand t of the organic matter or 21.7 thousand t C (Papchenkov, pers comm).

In 2005, the area occupied by higher aquatic plant cover equaled 19,830 ha (198.3 $\mathrm{km}^{2}$ ), and the area occupied by hygrohelophytes (air-aquatic plants) was 66.8 ha, helophyte (emergent plants) cover 6,817.8 ha, hygrophytes (submerged plants with floating leaves) 984.6 ha and fully submerged plants occupied 11,960.8 га (Papchenkov, pers comm). If we assume that the water layer contains $30 \%$ of air-aquatic plants and $70 \%$ of surface of the emergent plants, then the area of the surface of the macrophytes under the water equals 17,737.9 ha $\left(177.4 \mathrm{~km}^{2}\right)$.

Using these data, and also the results of assessing the number and biomass of the epiphyton components, we calculated the total biomass of the Reservoir's epiphyton, which equaled $124.67 \mathrm{t} \mathrm{C}$, which corresponded to only $0.6 \%$ of the biomass of the higher aquatic plants. The main component of the macrophytes' overgrowth was algae and cyanobacteria (Table 2).

\section{Table 2}

The Reservoir's mean values ( \pm mean error) of the number $(\mathrm{N})$ and biomass (B) of the main components of epyphyton and their share (\%) in the total epiphyton biomass of the Reservoir

\begin{tabular}{|c|c|c|c|c|c|}
\hline \multirow[b]{2}{*}{ Component } & \multirow[b]{2}{*}{$\mathrm{N}$, ind. $/ \mathrm{m}^{2}$} & \multicolumn{4}{|c|}{$\mathrm{B}$} \\
\hline & & $\mathrm{mg} / \mathrm{m}^{2}$ & $\begin{array}{c}\mathrm{mg} \\
\mathrm{C} / \mathrm{m}^{2}\end{array}$ & $\begin{array}{l}\mathrm{t} \text { C/water } \\
\text { body }\end{array}$ & $\begin{array}{c}\text { \% epiphyton } \\
\text { biomass }\end{array}$ \\
\hline Phytoepiphyton & - & $26.3 \pm 3.9^{*}$ & 658 & 116.73 & 93.63 \\
\hline Bacteria & $\begin{array}{l}(18.2 \pm 2.6) \\
\quad \times 10^{11}\end{array}$ & $202 \pm 27$ & 44 & 7.81 & 6.26 \\
\hline Viruses & $\begin{array}{l}(5.2 \pm 1.4) \\
\quad \times 10^{11}\end{array}$ & $0.2 \pm 0.05$ & 0.03 & 0.01 & 0.01 \\
\hline Flagellates & $\begin{array}{l}(1.4 \pm 0.3) \\
\quad \times 10^{8}\end{array}$ & $3.0 \pm 0.7$ & 0.7 & 0.12 & 0.10 \\
\hline Total & - & - & - & 124.67 & 100.00 \\
\hline
\end{tabular}

Note: * chlorophyll content.

Benthos. The biomass of phytobenthos in the Ivankovo Reservoir was assessed using the results of its assessment in the Ivankovo reach (Ekzertsev, 1978). In the second half of the summer, in the shallow area of the upper layer of the bottom sediments (less than $2 \mathrm{~m}$ depth), the phytobenthos biomass ranged within 4.8-6.1 $(5.5 \pm 0.3) \mathrm{g} / \mathrm{m}^{2}$, and in deeper areas (2-5 m deep) - within 1.6-19.2 (8.8 \pm 2.3$) \mathrm{g} / \mathrm{m}^{2}$. It should be mentioned that the phytobentos, apart from the typical "benthos" species constantly living in the bottom, contained algae and cyanobacteria, which live in the water column. According to our assessments, the Reservoir's mean biomass of phytobenthos, for both the shallow-water and deep areas, equaled $7.8 \mathrm{~g} / \mathrm{m}^{2}$ (Table 3).

The total biomass of benthos in the Reservoir equaled 16,580 t C. The main contribution to its formation was made by heterotrophic bacteria, the second greatest contribution by non-predatory invertebrates (Table 3). The proportion of the total biomass of phyto- and bacteriobenthos to the biomass of non-predatory zooplankton was $10: 1$. High concentrations of vegetative pigments (chlorophyll and products of its degradation - phaeopigments) in the upper 2-5 cm layer of the bottom sediments of the Reservoir (Sigareva, 2012) indicate a significant content of "dead" organic matter of vegetative origin, which is, most likely, an important food substrate for benthos organisms. The proportion of the biomass of non-predatory to the predatory zooplankton equaled $6: 1$, and the total biomass of zoobenthos to fish was $27: 1$.

Biotic component of the ecosystem. The total biomass of all autoand heterotrophic organisms, and also viruses which inhabit the Ivankovo Reservoir equaled 39853 t C. Above-the-bottom biomass (macrophytes with epiphyton and plankton) was 1.4 times higher than the biomass in the bottom sediments. At the same time, the total biomass of the plankton $(1,449$ t C) was significantly lower than the biomass of macrophytes with epiphyton (21,825 t C), and the biomass of benthos (16,580 t C). The main contribution to the formation of the total biomass of autotrophic organisms and to the formation of the total biomass of the biotic component was made by the higher water plants (Table 4). In the total biomass of animals, multicellular invertebrates predominated. At the same time, their biomass in the bottom deposits was ten times higher than in the water layer.

\section{Table 3}

The Reservoir's mean values ( \pm mean error) of the number $(\mathrm{N})$ and biomass $(\mathrm{B})$ of the main components of the benthos and their share (\%) in the total biomass of benthos in the Reservoir

\begin{tabular}{|c|c|c|c|c|c|}
\hline \multirow[b]{2}{*}{ Component } & \multirow[b]{2}{*}{$\mathrm{N}$, ind $/ \mathrm{m}^{2}$} & \multicolumn{4}{|c|}{$\mathrm{B}$} \\
\hline & & $\mathrm{mg} / \mathrm{m}^{2}$ & $\begin{array}{c}\mathrm{mg} \\
\mathrm{C} / \mathrm{m}^{2}\end{array}$ & $\begin{array}{l}\text { t C/water } \\
\text { body }\end{array}$ & $\begin{array}{c}\text { \% of } \\
\text { benthos } \\
\text { biomass }\end{array}$ \\
\hline Phytobenthos & - & 7800 & 780 & 255 & 1.54 \\
\hline Bacteria & $\begin{array}{c}(89.6 \pm 11.2) \\
\times 10^{13}\end{array}$ & $26.4 \times 10^{4}$ & 44632 & 14595 & 88.02 \\
\hline Viruses & $\begin{array}{c}(62.3 \pm 1.2) \times \\
10^{13}\end{array}$ & $51.4 \pm 5.2$ & 31 & 10 & 0.06 \\
\hline Flagellates & $\begin{array}{c}(12.8 \pm 0.5) \times \\
10^{9}\end{array}$ & $578 \pm 56$ & 125 & 41 & 0.25 \\
\hline Ciliates & $\begin{array}{c}(12.5 \pm 3.5) \times \\
10^{4}\end{array}$ & $69 \pm 13$ & 9 & 3 & 0.02 \\
\hline Sarcodina & $2.2 \times 10^{4}$ & 17 & 2 & 1 & 0.01 \\
\hline Meiobenthos & $\begin{array}{c}(224 \pm 70) \times \\
10^{3}\end{array}$ & $\begin{array}{c}6700 \pm \\
1900\end{array}$ & 663 & 217 & 1.31 \\
\hline Macrozoobenthos & $\begin{array}{c}(2.0 \pm 0.6) \times \\
10^{3}\end{array}$ & $\begin{array}{l}45306 \pm \\
32400\end{array}$ & 3588 & 1173 & 7.07 \\
\hline $\begin{array}{l}\text { Predatory } \\
\text { macrozoobenthos }\end{array}$ & $\frac{(0.4 \pm 0.2) \times}{10^{3}}$ & $\begin{array}{c}8630 \pm \\
4300\end{array}$ & 684 & 224 & 1.35 \\
\hline Demersal fish & - & 1700 & 185 & 61 & 0.37 \\
\hline
\end{tabular}

\section{Table 4}

Biomass of autotrophic and heterotrophic organisms and viruses and their shares (\%) in the total biomass of the biotic component of the Reservoir's ecosystem

\begin{tabular}{lrr}
\hline \multicolumn{1}{c}{ Component } & t C & $\begin{array}{c}\text { \% of the total } \\
\text { biomass }\end{array}$ \\
\hline Autotrophic organisms, including.: & 22744 & 57.07 \\
Algae + cyanobacteria & 1044 & 2.62 \\
Macrophytes & 21700 & 54.45 \\
Heterotrophic organisms, including.: & 17096 & 42.90 \\
Protozoa & 115 & 0.29 \\
Multicellular invertebrates & 1775 & 4.46 \\
Fish & 284 & 0.71 \\
Bacteria & 14922 & 37.44 \\
Viruses & 13 & 0.03 \\
The total biomass of the biotic component & 39853 & 100.00 \\
\hline
\end{tabular}

In share of the total biomass, the heterotrophic bacteria, most of which live in the bottom sediments, took second place after the macrophytes (Table 4). Finally, we determined that in the Reservoir the proportion of the biomass of autotrophic organisms (primary producers), invertebrates (consumers of the 1 and 2 orders), fish (the highest trophic level) and heterotrophic bacteria is $80: 7: 1: 53$.

Primary production of the organic matter. The primary production of the macrophytes during the vegetative season in 1979 equaled 68 thousand t of organic matter or 34 thousand t C (Pyrina \& Lyashenko, 2005). The annual production was assumed to be the total biomass of the above-ground parts of the plants in the flowering period, and the adjustment for their autumn increment was not made, and the loss during the leaf fall was not considered. The production of the higher aquatic plants during the vegetative season of 2005 was assessed as 43.6 thousand t of organic matter or 21.8 thousand t C (Papchenkov, pers comm). In our assessments, we used the production of macrophytes, obtained in 2005.

The production of epiphyton during the vegetative season in the Ivankovo Reservoir, assessed using the season's mean value of tempi of epiphyton photosynthesis among different species of macrophytes in the Rybinskoe Reservoir, equaled $8.3 \pm 2.7 \mu \mathrm{g} \mathrm{C} /\left(\mathrm{cm}^{2} \times\right.$ day $)$ (Kopylov et al., 2014), assessed as 2.7 thousand t C.

According to our data, the Reservoir's mean integral primary production of phytoplankton in August of 2005 equaled $1157 \pm$ $353 \mathrm{mg} \mathrm{C} /\left(\mathrm{m}^{2} \times\right.$ day) or $35.8 \mathrm{~g} \mathrm{C} /\left(\mathrm{m}^{2} \times\right.$ month). If we assume that the Ivankovo Reservoir, similarly to the Rybinskoe, has the primary production of phytoplankton in August equaling around $20 \%$ of the 
total 6-month (May to October)primary production of phytoplankton, then the primary production of the plankton over the vegetative season equaled $179 \mathrm{~g} \mathrm{C} / \mathrm{m}^{2}$, and 58.5 thousand $\mathrm{t} \mathrm{C}$ in the entire Reservoir.

On average, the tempi of phytobenthos photosynthesis in the shallow water area of the Reservoir in May-August equaled $195 \pm 135$ (ranging 0-860) $\mathrm{mg} \mathrm{O}_{2} /\left(\mathrm{m}^{2} \times\right.$ day) or $65 \pm 45 \mathrm{mg} \mathrm{C} /\left(\mathrm{m}^{2} \times\right.$ day). If we presume that the area of potential benthos photosynthesis (about $1 \mathrm{~m}$ depth) is comparable to the area of macrophyte overgrowth (29.2\%), then, considering the temperature adjustments in September-October, the primary production of phytobenthos over the vegetative period equaled 1.3 thousand $\mathrm{t} C$.

As a result, the total primary production of the organic matter in the Reservoir equaled 84.3 thousand $\mathrm{C}$ in the season. At the same time, the share of macrophytes, phytoepiphyton, phytoplankton and phytobenthos equaled $25.9 \%, 3.2 \%, 69.4 \%$ and $1.5 \%$ of the total biomass respectively, i.e. the main primary producers of the organic matter in the Reservoir were the plankton algae and cyanobacteria. At the same time, in the Reservoir, we observed a tendency towards gradual increase in the share of macrophytes in the total primary production.

\section{Discussion}

Currently, the Ivankovo Reservoir continues to become gradually overgrown by higher aquatic plants which make the greatest contribution to the formation of the total biomass of the ecosystem's biotic component. We observed a tendency towards an increasing contribution of macrophytes to the total primary production, which in 1973 equaled $22 \%$ of the total production of macrophytes and phytoplankton (Pyrina \& Lyashenko, 2005), and 27\% in 2005.

In freshwater ecosystems, part of the primary organic matter which is synthesized by the autotrophic organisms, does not become involved in the trophic web, and is deposited in the bottom. As the higher aquatic plants in the Reservoir develop, the dead parts of the macrophytes settle and accumulate. Their excess leads to the formation of floating mats of macrophytes, which after growing into the bottom, form land structures, separating a part of the water body (Papchenkov, 2013). The role of macrophytes in the carbon flows in the trophic web of the Ivankovo Reservoir remains undetermined. However, the observed processes of swamp-formation in the shallow-water areas, formation of floating mats (with total area of $50 \mathrm{~km}^{2}$ ) and colonisation of the floating mats by willows, the roots of which closely connect the mats to the bottom and shore, indicate that a significant part of the primary production of macrophytes is not consumed by hydrobionts.

In the Volga reservoirs, we observed an increase in the share of cyanobacteria in the total biomass of phytoplankton. A significant component of the Ivankovo Reservoir's phytoplankton was large colonial cyanobacteria (Korneva, 2015). Their ability to form large viscous colonies and synthesize toxins protects them from being eaten by zooplankton. In water bodies with a significant level of colonial cyanobacteria' development, plankton invertebrates usually consume not less than the half of primary production of phytoplankton (Stone et al., 1993; Kazantseva, 2003; Kopylov et al., 2010). Cyanobacteria and algae, which have lost their vitality and not been consumed, settle in the bottom from the water column, where they serve as a source of food for benthos heterotrophic organisms and participate in the formation of bottom sediments.

The high content of vegetative pigments in the upper layer of bottom sediments of the Ivankovo Reservoir, 1.6-1.8 times higher than in the other Upper Volga Reservoirs (Sigareva, 2012), indicates a signifycant sedimentation of the organic matter of plankton autotrophic organisms from the water column, which serves as a substrate for benthos organisms. The benthos biomass was assessed as ten times higher than the biomass of plankton. The main share in it was taken by heterotrophic bacteria, then multicellular invertebrates, the biomass of which in the bottom sediments was ten times higher than in the water column.

As demonstrated above, in the process of consumption of large colonial cyanobacteria (Microcystis aeruginosa) by fish (Carassius), the cyanobacteria maintained their photosynthesizing activity during their passage through the fish intestine, and moreover their passage through the intestine stimulated their growth. This direct stimulating effect of plankton-consuming fish on large colonial cyanobacteria can be a mechanism of intensifying and prolonging the "bloom" of the water caused by the cyanobacteria (Kolmakov et al., 2001).

In many aquatic ecosystems, a significant part of bacterio- and phytoplankton is lysed by viruses, leading to the carbon from their cells not being released to the higher levels of the trophic webs. Despite viruses being the minimum part of the plankton biomass, they are important for the functioning of the plankton community of the Ivankovo Reservoir: the death rate among the heterotrophic bacteria and picocyanobacteria as a result of virus lysis reached 35\% and 30\% of their daily production respectively (Kopylov et al., 2011). Perhaps, the cyanophage-viruses in the Ivankovo Reservoir, similarly to the other reservoirs (Honjo et al., 2006; Tijdens et al., 2008), control the number and the production of large colonial cyanobacteria which cause the "bloom" of the water.

Because the mass of even small (to $100 \mu \mathrm{m}$ ) detritus particles in the Ivankovo Reservoir, which are inhabited by the bacteria, is 1.6 times higher than the total biomass of the plankton community, we can presume that the detritus is significant for the feeding of zooplankton and planktonophage fish, which is also typical for other freshwater reservoirs (Kazantseva, 2003), and a large amount of bacteria is consumed with detritus.

The biomass of fish in the Reservoir equaled $15 \%$ of the biomass of their potential food objects - invertebrates - and $0.7 \%$ of the total biomass of the biotic component. According to Poddubnyy et al. (1984), the fish productivity of the Ivankovo Reservoir is around $20 \mathrm{~kg} / \mathrm{ha}$ (projected fish productivity $-45.9 \mathrm{~kg} / \mathrm{ha}$ ), which, according to our assessments, is equivalent to $8.4 \mathrm{t} \mathrm{C}$. The proportion of the primary production of the organic matter of all photosynthesizing organisms in the vegetative period to the annual fish production is $10,036: 1$. It is clear that not all of new formed organic matter enters the trophic webs of the Reservoir.

\section{Conclusion}

During the relatively short period of its existence, the Ivankovo Reservoir has developed as a eutrophic water body with the highest level of overgrowth by higher aquatic plants among the Volga Reservoirs. The total biomass of the organisms and viruses in the Resevoir equaled 39,853 t C. Favourable conditions allow the macrophytes to synthesize $54.5 \%$ of the biomass of all the living organisms over the vegetative season. At the same time, the main producer of the primary organic matter in the Reservoir was phytoplankton which produced $69.4 \%$ of the total primary production. Eutrophication of the water body is to a large extent determined by the intensive development of macrophytes, increase in their biomass and production. It is likely that the share of the macrophytes in the total primary production of the Reservoir will continue to increase. The production of the fish community was forty times lower than the primary production of organic matter by autotrophic organisms.

The total biomass of heterotrophic organisms and viruses was 1.3 times lower than the total biomass of autotrophic organisms. Heterotrophic bacteria are the main component of the total biomass of heterotrophic organisms and in second place after the macrophytes by their contribution to the total biomass of the biotic component. The biomass of all the benthos heterotrophic organisms was 27 times greater than that of plankton, 45 times greater than that of bacteria, and 7 times greater than that of invertebrates. The high concentration of bacteria and invertebrates in the bottom sediments of the Reservoir indicate significant provision of organic substrates from the water layer.

The increase in the biomass of phytoplankton in the Reservoir is to a large extent the result of intense development of cyanobacteria, including the species which form large colonies. Therefore, the amount of organic matter of vegetative origin, which settles down to the bottom from the water column, will further increase, hastening the tempi of its accumulation in the bottom sediments. Now already, in some areas of the Reservoir in late summer, due to the consumption of oxygen by 
the benthos microorganisms, its concentration in the prebottom water layer decreases to $0.02-0.40 \mathrm{mg} / \mathrm{l}$, which negatively influences the demersal multicellular animals.

Over the last few years, the conditions of high concentration of dissolved organic matter and low water transparency in the Reservoir have led to the increase in the content of nonheterocystic species of cyanobacteria capable of heterotrophic feeding and mixotrophic flagellates in the phytoplankton. Certainly, the organisms which combine the abilities of photosynthesis and heterotrophy are becoming a significant component of the plankton trophic web of the Reservoir.

The further eutrophication and increase in the total biomass of biotic component in the ecosystem of the Ivankovo Reservoir, despite the high intensity of the process of biotic natural purification, will be followed by decrease in the water quality. It is important to take this into account, because the Reservoir is an important source of water supply of the city of Moscow.

The study was conducted within the framework of the State order (Theme AAAA-A18-118012690098-5).

\section{References}

Abakumov, V., Akhmet'ev, N., \& Brekhovskikh, V. (2000). Ivan'kovskoye vodokhranilishche: Sovremennoye sostoyaniye i problemy okhrany [Ivankovo Reservoir: Current state and problems of protection]. Nauka, Moscow (in Russian).

Auer, B., Elzer, U., \& Arndt, H. (2004). Comparison of pelagic food webs in lakes along a trophic gradient and with seasonal aspects: Influence of resource and predation. Journal of Plankton Research, 26(6), 697-709.

Avakyan, A. B., Saltankin, V. P., \& Sharapov, V. A. (1987). Vodokhranilishcha [Reservoirs]. Mysl', Moscow (in Russian).

Børsheim, K. Y., \& Bratbak, G. (1987). Cell volume to carbon conversion factors for bacterivorous Monas sp. enriched from seawater. Marine Ecology Progress Series, 36, 171-175.

Christoffersen, K., Riemann, B., Hansen, L. R., Klysner, A., \& Sørensen, H. B. (1990). Qualitative importance of the microbial loop and plankton community structure in a eutrophic lake during a bloom of cyanobacteria. Microbial Ecology, 20(1), 253-272.

Chróst, R. J., Adamczewski, T., Kalinowska, K., \& Skowronska, A. (2009) Abundance and structure of microbial loop components (bacteria and protists) in lakes of different trophic status. Journal of Microbiology and Biotechnology, 19(9), 858-868.

Comerma, M., Garsia, J. C., Romero, M., Armengol, J., \& Simek, K. (2003). Carbon flow dynamics in the pelagic community of the Sau Reservoir (Catalonia, NE Spain). Hydrobiologia, 504(1-3), 87-98.

Cronin, G., Lewis Jr., W. M., \& Schiehser, M. A. (2006). Influence of freshwater macrophytes on the littoral ecosystem structure and function of a young Colorado reservoir. Aquatic Botany, 85(1), 37-43.

Degermendzhy, A. G., \& Gulati, R. D. (2002). Understanding the mechanisms of blooming of phytoplankton in Lake Shira, a saline lake in Siberia (the Republic of Khakasia). Aquatic Ecology, 36(2), 333-340.

Del Giorgio, P. A., \& Gasol, J. M. (1995). Biomass distribution in freshwater plankton communities. The American Naturalist, 146(1), 135-152.

Devyatkin, V. G. (1983). Intensivnost' fotosinteza mikrofitobentosa v Ivan'kovskom vodokhranilishche [Intensity of photosynthesis of microphytobenthos in the Ivankovo reservoir]. Biololgiya Vnutrennikh Vod, 59, 18-22 (in Russian).

Dumont, H. J., Van de Velde, I., \& Dumont, S. (1975). The dry weight estimate of biomass in selection of Cladocera, Copepoda and Rotifera from the plankton, periphyton and benthos of continental waters. Oecologia, 19(1), 75-97.

Ekzertsev, V. A. (1958). Produktsiya pribrezhno-vodnoy rastitel'nosti Ivan'kovskogo vodokhranilishcha [Production of coastal aquatic vegetation of the Ivankovo reservoir]. Byulleten' Instituta Biologii Vodokhranilishch, 1, 1921 (in Russian).

Ekzertsev, V. A. (ed.) (1978). Ivan'kovskoye vodokhranilishche i yego zhizn' [Ivankovo reservoir and its life]. Nauka, Leningrad (in Russian)

Fahnenstiel, G. L., Krause, A. E., McCormick, M. J., Carrick, H. J., \& Schelske, C. L. (1998). The structure of planktonic food web in the St. Lawrence Great Lakes. Journal of Great Lakes Research, 24(3), 531-554.

Hart, D. R., \& Stone, L. (2000). Seasonal dynamics of the Lake Kinneret food web: The importance of the microbial loop. Limnology and Oceanography, 45(2), 350-361.

Honjo, M., Matsui, K., Ueki, M., Nakamura, R., Fuhrman, J. A., \& Kawabata, Z. (2006). Diversity of virus-like agents killing Microcystis aeruginosa in a hyper-eutrophic pond. Journal of Plankton Research, 28(4), 407-412.
Kazantseva, T. I. (2003). Balansovaya model' ekosistemy melkogo vysokoevtrofnogo ozera [The balance model of the ecosystem of a small highlyeutrophic lake]. Zhurnal Obshchey Biologii, 64(2), 128-145 (in Russian).

Kolmakov, V. I., Gayevskiy, N. A., \& Gladyshev, M. I. (2001). Growth of blue-green microalgae passed through the Carassius auratus (Linnaeus) gut in blooming pond water. Doklady Biological Sciences, 376(1-6), 75-77.

Kolpakov, N. V. (2016). Produktsiya ryb v estuariyakh Primor'ya [Fish production in estuaries of Primorye]. Izvestiya Tikhookeanskogo Nauchno-Issledovatel'skogo Rybokhozyaystvennogo Tsentra, 184, 3-22 (in Russian).

Kopylov, A. I. (ed.) (2001). Ekologicheskiye problemy Verkhney Volgi [Ecological problems of the Upper Volga]. Izdatel'stvo Yaroslavskogo Gosudarstvennogo Tekhnicheskogo Universiteta, Yaroslavl' (in Russian).

Kopylov, A. I., \& Kosolapov, D. B. (2008). Bakterioplankton vodokhranilishch Verkhney i Sredney Volgi [Bacterioplankton of the reservoirs of the Upper and Middle Volga]. Izdatel'stvo Sovremennogo Gumanitarnogo Universiteta, Moscow (in Russian).

Kopylov, A. I., Lazareva, V. I., Pyrina, I. L., Myl'nikova, Z. M., \& Maslennikova, T. S. (2010). Mikrobnaya “petlya” v planktonnoy troficheskoy seti krupnogo ravninnogo vodokhranilishcha [Microbial "loop" in the planktonic trophic web of a large lowland reservoir]. Uspekhi Sovremennoy Biologii, 6, 544-556 (in Russian).

Kopylov, A. I., Kosolapov, D. B., \& Zabotkina, E. A. (2011). Virus impact on heterotrophic bacterioplankton of water reservoirs. Microbiology, 80(2), 228-236.

Kopylov, A. I., Kosolapov, D. B., Rybakova, I. V., \& Zabotkina, Y. A. (2014). Mikrobnoye soobshchestvo epifitona vodokhranilishcha: Rol' virusov v smertnosti geterotrofnykh bakteriy i pikotsianobakteriy [Microbial community of the reservoir epiphyton: The role of viruses in the mortality of heterotrophic bacteria and picocyanobacteria]. Uspekhi Sovremennoy Biologii, 134, 111-120 (in Russian).

Kopylov, A. I., Zabotkina, E. A., \& Romanenko, A. V. (2015).Viruses in bottom sediments of the eutrophic reservoir (Ivankovskoe Reservoir, Upper Volga). Inland Water Biology, 8(3), 236-241.

Korneva, L. G. (2015). Fitoplankton vodokhranilishch basseyna Volgi [Phytoplankton of reservoirs of the Volga basin]. Kostromskoy Pechatnyy Dom, Kostroma (in Russian).

Norland, S. (1993). The relationship between biomass and volume of bacteria. Handbook of Methods in Aquatic Microbial Ecology. Lewis Publishers, Boca Raton, FL. Pp. 303-308.

MacKay, M. D., Neale, P. J., Arp, C. D., De Senerpont Domis, L. N., Fang, X., Gal, G., Jöhnk, K. D., Kirillin, G., Lenters, J. D., Litchman, E., MacIntyre, S., Marsh, P., Melack, J., Mooij, W. M., Peeters, F., Quesada, A., Schladow, S. G., Schmid, M., Spence, C., \& Stokes, S. L. (2009). Modeling lakes and reservoirs in the climate system. Limnology and Oceanography, 54, 2315-2329.

Myl'nikova, Z. M. (1977). Bentosnyye infuzorii i sarkodovyye Rybinskogo vodokhranilishcha [Benthic ciliates and sarcode of the Rybinsk reservoir]. Biololgiya Vnutrennikh Vod, 35, 36-40 (in Russian).

Papchenkov, V. G. (2013). The degree of overgrowth of the Rybinsk Reservoir and productivity of its vegetation cover. Inland Water Biology, 6(1), 18-25.

Poddubnyy, A. G. (1988). Teoriya lokal'nykh stad ryb kak osnova upravleniya ryboproduk-tivnost'yu vnutrennikh vodoyemov [The theory of local fish shoals as a basis for managing fish productivity in the bodies of inland waters]. Trudy IBVV AN SSSR, 55, 142-163 (in Russian).

Poddubnyy, A. G., Volodin, V. M., Konobeyeva, V. K., \& Lapitskiy, I. I. (1984). Effektivnost' vosproizvodstva rybnykh zapasov v vodokhranilishchakh [Efficiency of reproduction of fish stocks in the reservoirs]. Biologicheskiye resursy vodokhranilishch. Nauka, Moscow. Pp. 204-227 (in Russian).

Pomeroy, L. R., Williams, P. J. B., Azam, F., \& Hobbie, J. E. (2007). The microbial loop. Oceanography, 20(2), 28-33.

Porter, K. G. (1996). Integrating the microbial loop and the classic food chain into a realistic planktonic food web. In: Food webs: Integration of patterns and dynamics. Chapman and Hall, New York.

Pyrina, I. L., \& Lyashenko, G. F. (2005). Mnogoletnyaya dinamika produktivnosti fitoplanktona i vysshey vodnoy rastitel'nosti i ikh rol' v produktivnosti organicheskogo veshchestva v zarastayushchem Ivan'kovskom vodokhranilishche [Long-term dynamics of the productivity of phytoplankton and higher aquatic vegetation and their role in the productivity of organic matter in the overgrown Ivankovo reservoir]. Biologiya Vnutrennikh Vod, 3, 48-56 (in Russian).

Reynolds, C. S. (2006). The ecology of phytoplankton. University Press, Cambridge.

Rodhe, W. (1948). Environmental requirements of freshwater plankton algae: Environmental studies in ecology of phytoplankton. Symbolae Botanicae Upsaliensis, 10(1), 1-149.

Rybakova, I. V., \& Kopylov, A. I. (2017). Heterotrophic bacteria in epiphyton of higher aquatic plants in the Ivankovo Reservoir. Inland Water Biology, 10(2), 239-242. 
Shcherbina, G. K. (2002). Struktura i funktsionirovaniye biotsenozov donnykh makrobespozvonochnykh verkhnevolzhskikh vodokhranilishch. In: Dinamika raznoobraziya gidrobiontov vo vnutrennikh vodoyemakh Rossii [Dynamics of the diversity of hydrobionts in the inland waters of Russia]. Izdatel'stvo Yaroslavskogo Gosudarstvennogo Tekhnicheskogo Universiteta, Yaroslavl'. Pp. 121-142 (in Russian).

Sigareva, L. Y. (2012). Khlorofill v donnykh otlozheniyakh volzhskikh vodoyemov. KMK, Moscow (in Russian).

Sipkay, C., Kiss, K. T., Vadadi-Fülöp, C., \& Hufnagel, L. (2009) Trend in research on the possible effects of climate concerning aquatic ecosystems with special emphasis on the modeling approach. Applied Ecology and Environmental Research, 7(2), 171-198.

Sommaruga, R. (1995). Microbial and classical food webs: A visit to a hypertrophic lake. FEMS Microbiology Ecology, 17(4), 257-270.

Steward, G. F., Fandino, L. B., Hollibaugh, J. T., Whitledge, T. E., \& Azam, F. (2007). Microbial biomass and viral infections of heterotrophic prokaryotes in the sub-surface layer of the Central Arctic. Deep Sea Research Part I Oceanographic Research Papers, 54(10), 1744-1757.

Stone, L., Berman, T., Bonner, R., Barry S., \& Weeks, S. W. (1993). Lake Kinneret: A seasonal model for carbon flux through the planktonic biota. Limnology and Oceanography, 38(8), 1680-1695.
Straile, D. (1998). Biomass allocation and carbon flow in the pelagic food web of Lake Constance. Advances in Limnology, 53, 545-563.

Strickland, J. D. H. (1960). Measuring the production of marine phytoplankton. Fisheries Research Board of Canada. Bulletin 122. Ottawa, Canada.

Tijdens, M., Van de Waal, D. B., Slovackova, H., Hoogveld, H. L., \& Gons, H. J. (2008). Estimates of bacterial and phytoplankton mortality caused by viral lysis and microzooplankton grazing in shallow eutrophic lake. Freshwater Biology, 53(6), 1126-1141.

Turley, C. M., Newell, R. C., \& Robins, D. B. (1986). Survival strategies of two small marine ciliates and their role in regulating bacterial community structure under experimental conditions. Marine Ecology Progress Series, 33(1), 59-70.

Vadeboncoeur, Y., \& Steinman, A. D. (2002). Periphyton function in lake ecosystems. The Scientific World Journal, 2, 1449-1468.

Wetzel, R. G. (1995). Death, detritus, and energy flow in aquatic ecosystems. Freshwater Biology, 33(1), 83-89.

Zhukova, A. A. (2005). Pervichnaya produktsiya planktona, epifitona, makrofitov i mikro-fitobentosa v litoral'nykh biotopakh oz. Naroch' [Primary production of plankton, epiphyton, macrophytes and microphytobenthos in the littoral biotopes of the Lake Naroch]. Vesnik Brestskaga Universiteta, Seryya Pryrodaznauchykh Navuk, 24, 79-84 (in Russian). 